\title{
Some problems with eyewitness identification
}

\section{Opinion}

Eyewitness identification is both the most persuasive and often the unreliable testimony. Why it is persuasive is easy to understand. The witness testified under oath that he or she actually saw the individual (often a criminal defendant) at the department store on the day of the robbery, pull a gun on the clerk and abscond with the cash in the register. Yet, we have very persuasive evidence that identifications are often unreliable. According to the National Registry of Exonerations, as of March 1, 2012 (the most recent figures), there were 873 exonerations. Of this group, $37 \%$ were exonerated with the help of DNA evidence; $63 \%$ without the use of DNA. Since 2000, exonerations have averaged 52 a year, or one a week, and $40 \%$ of them include DNA evidence. The most common causal factor that contributed to these exonerations is perjury or false accusation (51\%). The second most common reason is mistaken eyewitness identification (43\%). These $43 \%$ represent people who honestly believed that they saw someone, but we now know, often through DNA evidence, that they were wrong. ${ }^{1}$ For "rape and robbery, the false convictions we know about are overwhelmingly caused by mistaken eyewitness identifications - a problem that is almost entirely restricted to crimes committed by strangers . . ." Memories that are emotionally negative have greater potentiality to be flawed. ${ }^{3}$ One study examined intoxicated eyewitnesses -one group had 0.04 blood alcohol concentration. The second group had 0.07 blood alcohol concentration; the control group was alcohol-free. The typical blood alcohol-driving limit in the United States is .08. The study showed each group a staged kidnapping and, one week later, the study asked everyone to pick out the kidnappers out of a lineup. All three performed about the same, slightly better than chance. There were no significant effects of alcohol intoxication with respect to performance. ${ }^{4}$ All three groups - including the one where the witnesses were alcohol-free ---- performed poorly.

It is for these reasons that courts should (but do not) routinely allow defendants to request an out-of-court lineup. People v. Bradley say broadly that, "A criminal defendant does not have a constitutional right to participate in a lineup whenever he requests one." Other courts also reject any right to a line-up, but they allow the trial judge to order one, in the exercise of his discretion. Rather than allow a lineup if the trial court's discretion, ${ }^{6}$ it should be the general rule that defendants have a right to seek an out-of-court lineup, with the results disclosed to the jury, which can then evaluate that evidence. Most courts reject that common-sense solution, but it would bring a measure to justice to a flawed practice.

\section{Acknowledgments}

None.

\section{Conflicts of interest}

The authors declare that there is no conflict of interest.

${ }^{1}$ Samuel R. Gross and Michael Shaffer, Exonerations In The United States, 1989-2012, U of Michigan Public Law Working Paper No. 277; $7^{\text {th }}$ Annual Conference on Empirical Legal Studies Paper, HTTP://SSRN.COM ABSTRACT $=2092195$, https://poseidon01.ssrn.com/delivery.php? ID=1 3208808612107200408208307912710710812501800104709102200012 5083006124123094095122126045055003101126027111027072101100 0850750700090410230590840290290741161141231200050920010830 0011301909408609901508408509611910112106508012702307212409
Volume 5 Issue 5 - 2017

\author{
Ronald D Rotunda \\ Professor, Doy \& Dee Henley Chair, Distinguished Professor of \\ Jurisprudence, Chapman University, USA
}

Correspondence: Ronald D Rotunda, The Doy \& Dee Henley Chair and Distinguished Professor of Jurisprudence, Chapman University, Dale E. Fowler School of Law, One University Drive, Rm. 406, Orange, California, USA, Tel (7I4) 628-2698; Fax (7I4) 628-2576,Email rrotunda@chapman.edu

Received: October 17, 2017 | Published: November 17, 2017

$5114071011115066 \& E X T=$ pdf. See also, Samuel R. Gross et al., Exonerations in the United States, 1989 Through 2003, 95 J. CRIm. L. \& CRiminology, 523, 529-31 (2005).

${ }^{2}$ Samuel R. Gross and Michael Shaffer, ibid. at p. 4.

${ }^{3}$ Ronald D. Rotunda, The Ferguson, Missouri, Tragedy and the Future of Eyewitness Identification, Verdict: Legal Analysis and Commentary FROM JUSTIA, Dec. 15, 2014, http://verdict.justia.com/2014/12/15/fergusonmissouri-tragedy-future-eyewitness-identificatio

${ }^{4}$ Hagsand, Roos-af-Hjelmsäter, Granhag, Fahlke, and Söderpalm-Gordh, Do Sober Eyewitnesses Outperform Alcohol Intoxicated Eyewitnesses in a Lineup?, 5 The Eur. J. Psychol. Applied to Legal Context 23 (Jan. 2013).

546 N.Y.S.2d 437, 437 (App. Div. 1989). See also, People ex rel. Blassickv. Callahan, 50 Ill.2d 330, 334-35, 279 N.E.2d 1, 3 (1972): "We have specifically rejected the contention that [an] in-court identification of an accused without a lineup denies due process of law." (Citing cases, omitted here.)

${ }^{6}$ People v. Grady, 133 Misc. 2d 211, 227, 506 N.Y.S.2d 922, 932 (Sup. Ct.), aff'd, 125 A.D.2d 1011, 508 N.Y.S.2d 359 (1986): "it is undisputed that there is no constitutional requirement that a defense-requested in-court lineup be conducted. Rather, it is acknowledged that such a request is addressed to the sound discretion of the court."

Evans v. Superior Court, 11 Cal. 3d 617, 625, 114 Cal. Rptr. 121, 126, 522 P.2d 681, 686 (1974): "We conclude in view of the foregoing that due process requires in an appropriate case that an accused, upon timely request therefor[e], be afforded a pretrial lineup in which witnesses to the alleged criminal conduct can participate. The right to a lineup arises, however, only when eyewitness identification is shown to be in material issue and there exists a reasonable likelihood of a mistaken identification which a lineup would tend to resolve." (footnote omitted)

However, as a later California court observed, "We have some reservations whether a defendant's right to seek an Evans lineup survived the enactment of Proposition 115." People v. Mena, 173 Cal. App. 4th 1446, 93 Cal. Rptr. 3d 845,849 , review granted and opinion superseded, 99 Cal. Rptr. 3d 561 (Cal. 2009), and aff'd, 54 Cal. 4th 146, 277 P.3d 160, 141 Cal. Rptr. 3d 469, 215 P.3d 1063 (2012), stating that any error in the denial of a physical lineup was harmless.

See the thorough analysis in, Brandon L. Garrett, Eyewitnesses and Exclusion, 65 Vanderbilt L. Rev. 451 (2012). Professor Garret concludes, "The regulation of eyewitness identifications should start with the fundamental requirement that law enforcement follow best practices when conducting identification procedures in the first instance, and it could include per se exclusion of courtroom identifications that follow prior identifications." 65 VANDERBILt L. Rev. 451, 497. 